\title{
Relationships between residual feed intake and feedlot performance, profitability, and carcass traits in Brahman cattle
}

[Relações entre consumo alimentar residual e desempenho em confinamento, lucratividade e características de carcaça de bovinos da raça Brahman]

R. Favero ${ }^{1}$, I.Y. Mizubuti ${ }^{1}$, R.C. Gomes ${ }^{2}$, E.L.A. Ribeiro ${ }^{1}$, E.S. Pereira ${ }^{3}$, O.P.P. Prado-Calixto ${ }^{1}$, F.L. Massaro Júnior ${ }^{1}$, A.P.S. Santos ${ }^{4}$

${ }^{1}$ Universidade Estadual de Londrina - Londrina, PR

${ }^{2}$ Embrapa Gado de Corte - Campo Grande, MS

${ }^{3}$ Universidade Federal do Ceará - Fortaleza, CE

${ }^{4}$ Universidade Federal de Uberlândia - Uberlândia, MG

\begin{abstract}
The present study aimed to evaluate the feedlot performance, profitability and carcass traits of Brahman bulls classified according to the residual feed intake (RFI). Twenty-four bulls (19-month old, $370 \pm 34 \mathrm{~kg}$ live weight) were housed in individual pens for 54 days and had the daily feed intake (observed dry matter intake, $\mathrm{DMI}_{\mathrm{obs}}$; DMI \% live weight, $\mathrm{LW}$ ) and average daily gain (ADG) measured. Ultrasound carcass evaluations were performed at the initial and final weighings, when measurements were taken of Longissimus dorsi area, ratio, Longissimus and Biceps femoris fat thickness. The animals were ranked and divided into high ( $>+0.5$ standard deviation; SD), medium (between $\pm 0.5 \mathrm{SD}$ from the mean), and low (<0.5 SD) RFI groups. Low-RFI animals had lower $\mathrm{DMI}_{\mathrm{obs}}(\mathrm{P}<0.10)$ and DMI \% LW $(\mathrm{P}<0.05)$. No significant differences in initial and final weight or ADG were noticed $(\mathrm{P}>0.05)$. Low-RFI animals showed lower weight gain cost and higher daily profit $(\mathrm{P}<0.05)$. Carcass traits were similar between groups, regardless of evaluation date ( $>0.05)$. Selection for RFI lead to animals with lower feed intake without affecting weight gain or carcass traits, thereby providing increased profitability for beef cattle farming.
\end{abstract}

Keywords: Bos indicus, feed conversion ratio, musculature, phenotype

\section{RESUMO}

Objetivou-se avaliar o desempenho, o lucro e as características de carcaça de tourinhos Brahman classificados de acordo com o consumo alimentar residual (CAR). Vinte e quatro tourinhos (19 meses de idade e $370 \pm 34 \mathrm{~kg}$ de peso vivo) foram alojados em baias individuais por 54 dias para avaliação do consumo de alimentos $\left(C M S_{o b s} ; C M S \%\right.$ peso vivo, $\left.P V\right)$ e ganho de peso diário (GMD). Avaliações de carcaça por ultrassonografia foram realizadas nas pesagens inicial e final, com mensurações da área do Longissimus dorsi, ratio, espessura de gordura sobre o Longissimus e sobre o Biceps femoris. Os animais foram ranqueados e divididos em grupos de alto $(>+0,5$ desvio-padrão; $D P$ ), médio (entre $\pm 0,5$ $D P$ da média) e baixo (<-0,5 DP) CAR. Animais de baixo CAR apresentaram menor $C M S_{\text {obs }}(P<0,10) e$ menor CMS \% PV $(P<0,05)$. Não houve diferença nos pesos inicial e final e GMD $(P>0,05)$. Animais de baixo CAR apresentaram menor custo do ganho de peso e maior lucro diário $(P<0,05)$. As características de carcaça foram semelhantes entre os grupos independentemente da data de avaliação $(P>0,05)$. A seleção para CAR leva a animais de menor consumo, sem afetar o ganho de peso e as características de carcaça, fornecendo maior lucro para a atividade pecuária.

Palavras-chave: Bos indicus, conversão alimentar, musculatura, fenótipo

Recebido em 17 de outubro de 2016

Aceito em 5 de julho de 2017

E-mail: ricardo.mvet@yahoo.com.br 


\section{INTRODUCTION}

Approximately $70 \%$ of the total energy consumption in beef cattle production systems is exclusively intended to meet the maintenance requirements of animals (Nutrient..., 1996). Accordingly, selection based on classic efficiency measures, including feed conversion (FC) and gross feed efficiency (GFE), may fail to improve whole-system efficiency. This is because such measures are strongly correlated with weight gain and live weight, thereby causing increases in both adult weight and maintenance requirements of animals, which raises the costs of maintaining dams in herds (Arthur et al., 2001).

Residual feed intake (RFI) has been widely discussed and proposed as an advantageous alternative selection measure in production systems because it prioritizes low-intake and low-maintenance animals, without changing adult weight or weight gain, thereby considerably reducing production costs (Koch et al., 1963). Furthermore, studies indicate that high-efficiency animals, based on the RFI, emit fewer pollutants per unit of meat produced, especially enteric methane (Nkrumah et al., 2006).

The effects of selection for RFI on carcass traits, despite its advantages, are still somewhat controversial and require further clarification. Although some authors have shown that the carcasses of high-efficiency animals tend to have low subcutaneous and intramuscular fat (Basarab et al., 2003), other studies have found no differences in such traits between high- and lowRFI animals (Cruz et al., 2010; Gomes et al., 2012; Zorzi et al., 2013).

Few studies to date have been conducted with the purpose of assessing feed efficiency and the effects of selection for RFI on key production traits in Brahman cattle. Brahman cattle, a zebu breed (Bos indicus), is an alternative to the Nellore breed for Brazilian beef cattle farmers, given its high adaptability to tropical environments and attractive feedlot performance and carcass traits, even in crossbreeding programs. Furthermore, the relationship between selection for feed efficiency and economic responses must be known in order to estimate the possible benefits of this process.

The present study therefore aimed to evaluate potential differences in feedlot performance, profitability, and carcass traits in Brahman bulls, classified into feed efficiency groups according to the RFI.

\section{MATERIAL AND METHODS}

The study was approved by the Committee of Ethics in Animal Use of Universidade Estadual de Londrina, process \# 14301.2012.19 and was conducted in Uberlândia, in the state of Minas Gerais, Brazil (1851'20" S, 48 21'51" W and $863 \mathrm{~m})$. Animals were selected for the study on the basis of a grazing weight gain test conducted between Aug. and May, during which they were maintained in eight pasture areas containing Brachiaria brizantha cv. Marandu (bread grass) for a period of 294 days, in a rotational grazing system. The animals were supplemented during the rainy season by a protein-energy supplement containing $45 \%$ total digestible nutrients (TDN) and $20 \%$ crude protein $(\mathrm{CP})$, provided according to the estimated intake of $3 \mathrm{~g} \mathrm{~kg} \mathrm{LW}^{-1}$ and in the dry season by a protein salt containing $30 \% \mathrm{CP}$ provided ad libitum.

After completion of the grazing period, 24 Brahman bulls, with a mean age of 19 months and mean initial weight of $370 \pm 34 \mathrm{~kg}$, were individually housed in an experimental feedlot fitted with $20-\mathrm{m}^{2}$ roofless pens, each equipped with a feeder, drinker, and shade for thermal comfort, to evaluate feed efficiency. The animals were first subjected to a 14-day period of adaptation to the facilities and diet, then fed a total mixed ration (TMR) containing $73.5 \%$ TDN and $14.5 \% \mathrm{CP}$ and consisting of corn silage and concentrate at a 40:60 roughage:concentrate ratio for the remaining 54 days (Table 1). Feeding was conducted twice daily, at $07 \mathrm{~h} 00$ and $16 \mathrm{~h} 00$, and each diet was adjusted daily so that unused feed was maintained between $5 \%$ and $10 \%$ of the feed provided. The surplus feed was collected and weighed, and subsamples taken daily to prepare a weekly composite sample to be used for determining the feed dry matter (\% DM). 
Table 1. Percentage and chemical composition and energy content of the experimental diet

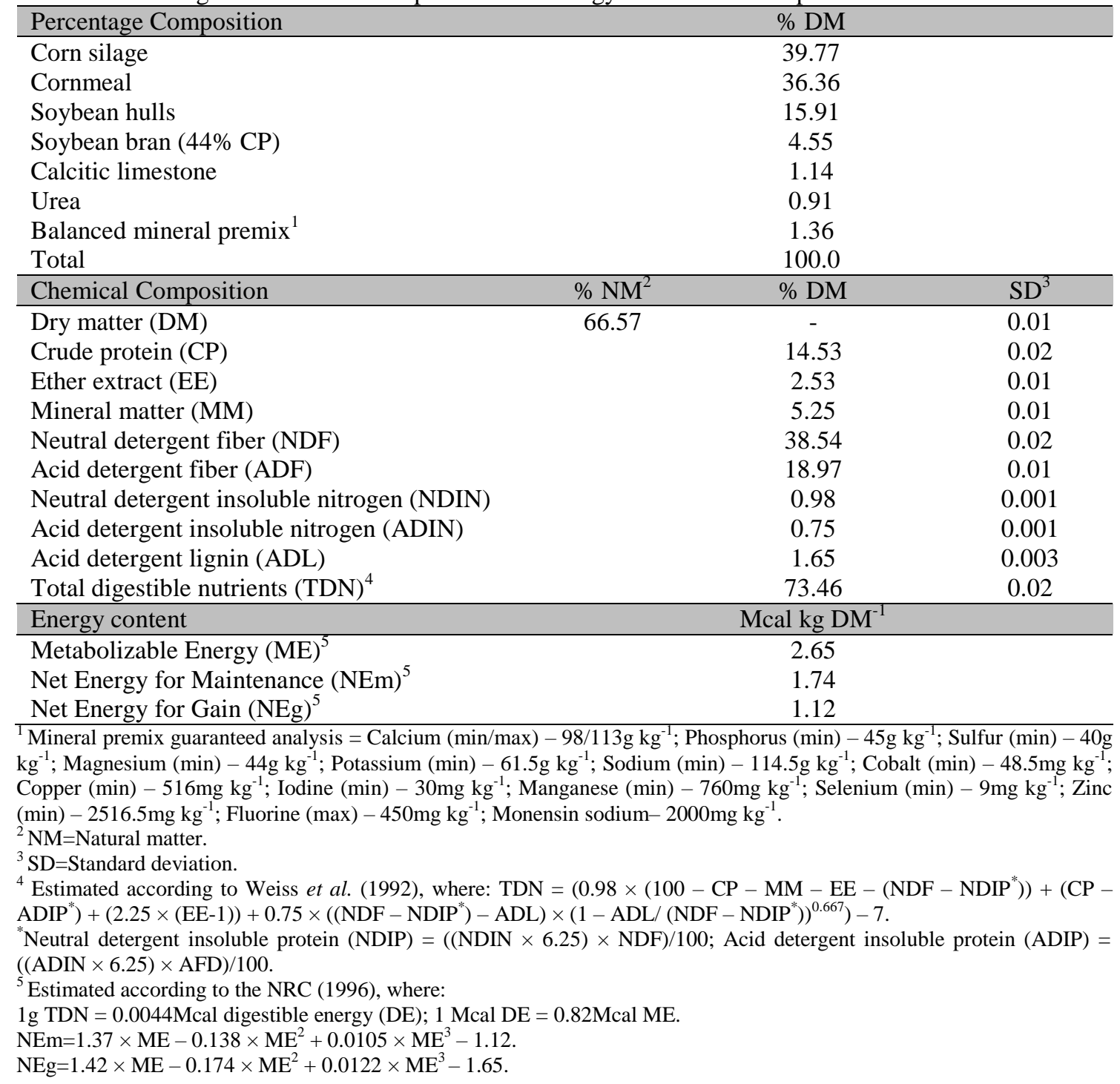

Feed subsamples were collected daily to prepare samples of roughage, concentrate, and surplus for bromatological analysis. After two weeks, these subsamples were pooled and homogenized to prepare composite samples, totaling four composite samples of silage, four samples of concentrate, and four of unused feed. The samples were initially stored in a freezer at $20^{\circ} \mathrm{C}$, and subsequently taken to a feed analysis laboratory to determine their chemical composition according to Mizubuti et al. (2009) and Detmann et al. (2012). The TDN content of TMR was estimated according to Weiss et al. (1992; Table 1).
The observed dry matter intake $\left(\mathrm{DMI}_{\mathrm{obs}}, \mathrm{kg}\right.$ day ${ }^{-}$ 1) was determined daily as the difference between the quantity of feed provided and the unused food collected daily during the feedlot period, adjusted for DM. Mean daily weight gain (ADG, kg day ${ }^{-1}$ ) was calculated as the linear regression slope between feedlot time and individual live weight ( $\mathrm{LW}, \mathrm{kg}$ ) measured on days $0,14,28,42$ and 54 during the experimental period. Weighings were not preceded by water or food fasting, except when assessing the initial (LWI, day 0) and final (LWF, day 54) live weights, which were used to calculate the mean metabolic live weights $\left(\mathrm{MLW}^{0.75}\right)$ using the formula: $\mathrm{MLW}=[(\mathrm{LWI}+\mathrm{LWF}) / 2]^{0.75}$. In these 
cases, the animals were deprived of food for an 18-hour period prior to being weighed.

Feed conversion (FC) was calculated as the ratio between DMI and ADG, and gross feed efficiency (GFE) as the ratio between ADG and DMI. The method described by Koch et al. (1963) was used to calculate the RFI (kg DM day $\left.^{-1}\right)$, and the predicted DMI (DMI ${ }_{\text {pred }}$ ) values were obtained using the REG procedure from Statistical Analysis System (2008) by estimating the regression of $\mathrm{DMI}_{\mathrm{obs}}$ based on $\mathrm{MLW}^{0.75}$ and ADG, as follows:

$\mathrm{DMI}_{\mathrm{obs}}=\beta_{0}+\beta_{1} \times\left(\mathrm{MLW}^{0.75}\right)+\beta_{2} \times(\mathrm{ADG})+\varepsilon$

The following equation was used to determine $\mathrm{DMI}_{\text {pred }}$ :

$\mathrm{DMI}_{\text {pred }}=-5.14105+0.143495 \times \mathrm{MLW}^{0.75}+$

$1.421201 \times \mathrm{ADG} ;\left(\mathrm{R}^{2}=0.64\right)$

The RFI of each animal was then calculated as the difference between $\mathrm{DMI}_{\mathrm{obs}}$ and $\mathrm{DMI}_{\text {pred }}$. The residual weight gain $\left(\mathrm{RG} ; \mathrm{kg} \mathrm{day}^{-1}\right)$ was obtained from the predicted daily weight gain $\left(\mathrm{ADG}_{\mathrm{pred}}\right)$, which was determined by regression of the observed ADG $\left(\mathrm{ADG}_{\mathrm{obs}}\right)$ based on the $\mathrm{MLW}^{0.75}$ and DMI (Koch et al., 1963), using the REG procedure of the SAS (SAS, 2008):

$\mathrm{ADG}_{\mathrm{obs}}=\beta_{0}+\beta_{1} \times\left(\mathrm{MLW}^{0.75}\right)+\beta_{2} \times(\mathrm{DMI})+\varepsilon$

The following equation was used to determine the $\mathrm{ADG}_{\text {pred }}$ :

$\mathrm{ADG}_{\text {pred }}=-1.40424+0.032314 \times \mathrm{MLW}^{0.75}+$ $0.048372 \times \mathrm{DMI} ;\left(\mathrm{R}^{2}=0.69\right)$

The RG was then determined by calculating the difference between $\mathrm{ADG}_{\mathrm{obs}}$ and $\mathrm{ADG}_{\text {pred }}$. RFI and $R G$ values were adjusted for variance 1 , and the RFI was then multiplied by -1 and the resulting values added to the RG values in order to calculate residual intake and gain (RIG), according to Berry and Crowley (2012).

The animals were ranked based on RFI and divided into high (low efficiency; $>0.5$ standard deviation (SD) above the mean), medium (median efficiency; between \pm 0.5 SD from the mean), and low (high efficiency; <0.5 SD below the mean) RFI groups.

The financial analysis was performed by considering the daily revenue (US\$ $\mathrm{day}^{-1}$ ) and the costs of daily weight gain (US $\$ \mathrm{~kg}^{-1}$ ), which were based on fixed and variable expenses during the feed efficiency evaluation period. The variable cost of feeding was calculated based on the cost of feed (US\$ 0.31 per $\mathrm{kg} \mathrm{DM}$ ) and
$\mathrm{DMI}_{\mathrm{obs}}\left(\mathrm{kg} \mathrm{day}^{-1}\right)$. The purchase cost of animals adopted for simulation was US\$ 41.84 per arroba $(14.7 \mathrm{~kg})$, a rate at use in the Triângulo Mineiro region, Minas Gerais, during June 2012.

The cost-benefit analysis provided by a commercial feedlot was used as the basis for an estimate of fixed and variable costs unrelated to direct payments of feed or animal purchases. A daily cost of US\$ 0.24 per animal, corresponding to an average feedlot period of 90 days and $9.78 \mathrm{~kg}$ DM day ${ }^{-1}$ mean intake, was used as a reference. A total of $33 \%$ of this value was considered as fixed costs (US\$ 0.08 per animal), $33 \%$ was taken as variable costs dependent on feedlot time [(US\$ $0.08 \times$ feedlot time) / 90], and the remaining $33 \%$ was taken as variable costs dependent on dry matter intake [(US\$ $0.08 \times$ DMI) / 9.78]. Total costs were then determined by adding the cost of feeding, the interest on capital invested in the purchase of animals and feed, variable costs dependent on feedlot time, and dry matter intake and fixed costs.

The total yield gain (TYG) was calculated based on the initial (ILWf) and final (FLWf) fasting live weight, and with the initial (CYi) and final (CYf) cold carcass yield set at $52 \%$ and $54 \%$, respectively:

$$
\mathrm{TYG}=\frac{\mathrm{CYf}-[(\mathrm{ILWf} / \mathrm{FLWf}) \times 100 \times \mathrm{CYi}]}{100-[100 \times(\mathrm{ILWf} / \mathrm{FLWf})]}
$$

The daily gross revenue (DGR, US\$ day ${ }^{-1}$ ) was then calculated based on the ADG $\left(\mathrm{kg} \mathrm{day}^{-1}\right)$, total yield gain (TYG) and price per arroba of live cattle. The sale price of the animals was set at US\$ 42.42 per arroba, the rate used in the Triângulo Mineiro region, Minas Gerais, in Aug. 2012.

$\mathrm{DGR}=\mathrm{ADG} \times \mathrm{TYG} \times($ price per arroba $/ 15)$

The daily profit (US\$ day ${ }^{-1}$ ) was calculated using the difference between the daily gross revenue and costs of daily weight gain, adopting the total cost structure.

Ultrasound carcass evaluations were conducted alongside the initial and final weighings (experimental days 0 and 54). Images of the Longissimus dorsi muscle (in the area between the $12^{\text {th }}$ and $13^{\text {th }}$ ribs) and the Biceps femoris muscle were recorded using an Aloka SSD 500 
(Hitachi Aloka Medical, Ltd., Wallingford) with a $17-\mathrm{cm}$ linear probe and $3.5 \mathrm{MHz}$ frequency, in order to assess the following measurements: ribeye area $\left(\mathrm{REA}, \mathrm{cm}^{2}\right)$, Longissimus dorsi (ribeye) subcutaneous fat thickness (BFT, mm), Biceps femoris (rump, RP) fat thickness (RFT, $\mathrm{mm}$ ) and ratio between ribeye height and width (REA ratio). Ribeye area, adjusted for live weight (REA $100 \mathrm{~kg}^{-1}, \mathrm{~cm}^{2}$ ), was calculated using the formula: [(REA / LW) x 100]. Gains throughout the experimental period were also calculated by subtracting the initial from the final values.

All data were evaluated for normality of residuals, homogeneity of variance, and the presence of outliers (>3 SD from the mean), using the UNIVARIATE procedure from SAS (Statistical..., 2008). The efficiency group effect on all the aforementioned traits was evaluated using a one-way analysis of variance, and means were compared using a Tukey's test, where necessary. The significance level was set at $5 \%$. Also, Pearson's simple correlations were estimated using the CORR procedure from SAS (Statistical..., 2008), being considered significant at $5 \%$.

\section{RESULTS AND DISCUSSION}

In the study population, the RFI maximum, minimum, and $\mathrm{SD}$ values were $+1.35,-1.58$, and $0.79 \mathrm{~kg}$ DM day ${ }^{-1}$, respectively, thus revealing considerable phenotypic variability for this trait in Brahman bulls. SD values similar to that assessed in this study have been found in other studies on zebu, taurine, and hybrid breeds of beef cattle. Gomes et al. (2012) observed an SD of $0.69 \mathrm{~kg} \mathrm{DM}$ day $^{-1}$ when evaluating Nellore steers; Nkrumah et al. (2007) found an SD of $0.88 \mathrm{~kg} \mathrm{DM}$ day $^{-1}$ when studying crossbred taurine beef cattle; and Lancaster et al. (2009) observed a mean SD of $0.71 \mathrm{~kg} \mathrm{DM}$ day $^{-1}$ when analyzing data collected from four RFI tests in Brangus heifers.

Four animals (17\% of the total) had a high RFI, twelve $(50 \%)$ were classified as medium-RFI animals, and seven (29\%) were classified as lowRFI animals, according to the criterion used to rank the animals. One animal (4\%) was classified as an outlier because it had an RFI more than three SD above the group mean (Table 2).

Table 2. Feedlot performance and economic evaluation of Brahman bulls classified according to residual feed intake

\begin{tabular}{|c|c|c|c|c|c|}
\hline \multirow{2}{*}{ Traits } & \multicolumn{3}{|c|}{$\mathrm{RFI}^{1}$} & \multirow{2}{*}{ SEM $^{2}$} & \multirow{2}{*}{$\mathrm{P}>\mathrm{F}^{3}$} \\
\hline & High & Medium & Low & & \\
\hline Animals per group, $n$ & 4 & 12 & 7 & & \\
\hline RFI, kg DM ${ }^{4}$ day $^{-1}$ & $0.97^{\mathrm{c}}$ & $0.04^{\mathrm{b}}$ & $-1.10^{\mathrm{a}}$ & 0.17 & $<0.0001$ \\
\hline Age, days & 557 & 566 & 583 & 6.05 & 0.32 \\
\hline Dry matter intake, $\mathrm{kg}$ day $^{-1}$ & 12.5 & 11.7 & 10.4 & 0.36 & 0.08 \\
\hline Dry matter intake, $\% \mathrm{LW}^{5}$ & $2.9^{\mathrm{c}}$ & $2.7^{\mathrm{b}}$ & $2.4^{\mathrm{a}}$ & 0.05 & $<0.0001$ \\
\hline Initial live weight, $\mathrm{kg}$ & 378 & 370 & 368 & 6.91 & 0.90 \\
\hline Final live weight, $\mathrm{kg}$ & 488 & 491 & 485 & 9.88 & 0.97 \\
\hline Mean metabolic live weight, $\mathrm{kg}$ & 95.3 & 94.6 & 94.1 & 1.38 & 0.96 \\
\hline Daily weight gain, $\mathrm{kg}$ day $^{-1}$ & 2.11 & 2.25 & 2.19 & 0.07 & 0.78 \\
\hline Feed conversion & $5.95^{\mathrm{c}}$ & $5.24^{\mathrm{b}}$ & $4.76^{\mathrm{a}}$ & 0.12 & 0.0003 \\
\hline Gross feed efficiency & $0.17^{\mathrm{c}}$ & $0.19^{\mathrm{b}}$ & $0.21^{\mathrm{a}}$ & 0.004 & 0.0003 \\
\hline Residual weight gain, $\mathrm{kg}$ day $^{-1}$ & -0.17 & 0.03 & 0.05 & 0.04 & 0.14 \\
\hline Residual intake and gain & $-1.83^{\mathrm{c}}$ & $0.14^{\mathrm{b}}$ & $1.32^{\mathrm{a}}$ & 0.32 & 0.0003 \\
\hline Daily gross revenue, US\$ day ${ }^{-1}$ & 3.64 & 3.87 & 3.75 & 0.12 & 0.79 \\
\hline Cost of gain, US $\$ \mathrm{~kg}^{-1}$ & $2.03^{\mathrm{b}}$ & $1.80^{\mathrm{a}}$ & $1.65^{\mathrm{a}}$ & 0.04 & 0.0008 \\
\hline Profit, US\$ day ${ }^{-1}$ & $-0.64^{\mathrm{c}}$ & $-0.18^{\mathrm{b}}$ & $0.14^{\mathrm{a}}$ & 0.08 & $<0.0001$ \\
\hline $\begin{array}{l}{ }^{1} \text { RFI = residual feed intake; least sc } \\
\text { Tukey-Kramer test }(\alpha=0.05) . \\
{ }^{2} \text { Standard error of the mean. } \\
{ }^{3} \text { Type I error rate or significance lev } \\
{ }^{4} \text { Dry matter. } \\
{ }^{5} \text { Live weight. }\end{array}$ & & & & cording & le adjusted \\
\hline
\end{tabular}


The mean RFI of the most efficient and the least efficient group of animals was $-1.10 \mathrm{~kg} \mathrm{DM}$ day $^{-1}$ and $+0.97 \mathrm{~kg} \mathrm{DM} \mathrm{day}^{-1}$, respectively, making a total difference of $2.07 \mathrm{~kg} \mathrm{DM}$ day $^{-1}$ between the groups. This difference was larger than that found by Ahola et al. (2011) in their evaluation of Angus steers, in which RFI values between efficiency groups ranged from -0.69 to $+0.62 \mathrm{~kg}$ $\mathrm{DM}$ day $^{-1}$, a difference of $1.31 \mathrm{~kg} \mathrm{DM}$ day $^{-1}$. The difference was also larger than the values found by Gomes et al. (2012) in their comparison of groups of high- and low- efficiency Nellore steers, in which values ranged from -0.97 to $+0.81 \mathrm{~kg}^{\mathrm{DM}}$ day $^{-1}$, a variation of $1.78 \mathrm{~kg} \mathrm{DM}$ day $^{-1}$.

The animals from the low-RFI (high-efficiency) group had a significantly $(\mathrm{P}<0.10)$ reduced dry matter intake compared to the medium- (medianefficiency) and high- (low-efficiency) RFI groups (Table 2). Low-RFI animals had a $13 \%$ lower daily DMI than medium-RFI animals, corresponding to a difference of $1.32 \mathrm{~kg}$ DMS day $^{-1}$, and a $21 \%$ lower daily DMI than high-RFI animals, that is, $2.14 \mathrm{~kg} \mathrm{DM} \mathrm{day}{ }^{-1}$. The difference in intake observed between groups of animals was slightly higher than the values recorded by other authors. Santana et al. (2012) observed that low-RFI Nellore bulls had a $15 \%$ lower DMI than high-RFI animals. Castro Bulle et al. (2007) also observed a $15 \%$ difference in intake between high- and low-efficiency animals when studying Angus x Hereford crossbred cattle, and Bingham et al. (2009) observed an $18 \%$ lower DMI in low-RFI Brangus heifers compared with high-RFI heifers. In the present study, a moderate positive correlation was obtained between RFI and DMI ( $\mathrm{r}=0.49$; $\mathrm{P}<0.05)$. Berry and Crowley (2012) and Santana et al. (2012) also found moderate positive correlations between RFI and DMI, of $r=0.58$ and $r=0.67$, respectively.

The dry matter intake calculated based on live weight (DMI \% LW) was significantly $(\mathrm{P}<0.05)$ affected by RFI, and high-efficiency animals had a lower DMI \% LW than medium- and high-RFI animals (Table 2), thus indicating that these animals have lower requirements, given the similar weight gain between groups.

No significant $(\mathrm{P}>0.05)$ difference in initial and final live weight, mean metabolic weight, and daily weight gain was found between efficiency groups (Table 2) and the weak phenotypic correlations observed between RFI and MLW ${ }^{0.75}$ $(\mathrm{r}=0.02)$ and ADG ( $\mathrm{r}=-0.03)$ were not significant (P>0.05). Santana et al. (2012) also found no significant differences in these indices, and noted the absence of any phenotypic correlation between this efficiency measure and such performance indices, as also observed by Basarab et al. (2003) and Ahola et al. (2011), indicating these variables are independent of each other. The results obtained corroborate the statements of Koch et al. (1963), Arthur et al. (2001) and Basarab et al. (2003) that RFI is phenotypically independent of the traits of live weight and weight gain, and selects for lowintake animals.

Low-RFI animals were significantly $(\mathrm{P}<0.05)$ superior to the other two efficiency groups in terms of feed conversion (FC) and gross feed efficiency (GFE; Table 2), justifying the strong correlations verified between RFI and FC $(\mathrm{r}=0.74 ; \mathrm{P}<0.001)$ and GFE $(\mathrm{r}=-0.74 ; \mathrm{P}<0.001)$. Crowley et al. (2010) also observed that animals with a high-efficiency of RFI were superior in terms of FC, based on evaluating the intake and performance data of 2,605 beef bulls of European breeds. The phenotypic correlation between RFI and FC ranges from 0.42 to 0.76 , indicating selection in the same direction, according to findings reported in the literature (Herd and Bishop, 2000; Arthur et al., 2001; Nkrumah et al., 2007). Conversely, Santana et al. (2012) observed no differences in GFE between efficiency groups, and assessed a moderate correlation $(-0.32)$ between RFI and GFE.

The groups of animals formed based on the RFI showed no differences with respect to the RG $(\mathrm{P}>0.05)$, mainly because these measures are calculated based on different variables. RFI is assessed based on feed intake and RG on weight gain. In this study, there was verified a weak negative correlation between RFI and RG ( $r=-$ $0.28)$, however it was not significant $(\mathrm{P}>0.05)$. Berry and Crowley (2012) observed that the phenotypic correlation between such measures can be moderate and negative $(r=-0.40)$.

The RIG, calculated by adding RFI and RG together, was affected according to the efficiency group being considered $(\mathrm{P}<0.05)$; low-RFI animals also showed high efficiency with respect to RIG (Tab. 2). A strong negative correlation 
was observed between RFI and RIG ( $\mathrm{r}=-0.73$; $\mathrm{P}<0.001)$, similar to Berry and Crowley (2012) who also verified a strong negative correlation between these measures ( $r=-0.87$ ), suggesting that, similarly to FC and GFE, RIG also follows the same selection direction as RFI, with the advantage of a stronger correlation with weight gain because it includes the RG.

No significant difference $(\mathrm{P}>0.05)$ in daily gross revenue was found between the feed efficiency groups of study animals, because this variable is determined based on live weight and weight gain, which are indices that are independent of the RFI and similar between groups, in terms of the financial analysis.

However, the cost-of-gain was significantly $(\mathrm{P}<0.05)$ different between groups of high- and low-RFI animals, decreasing with decreasing RFI mainly because this index is directly affected by the DMI, which was lowest among high-efficiency animals. The strong positive correlation found between cost-of-gain and RFI $(\mathrm{r}=0.70 ; \mathrm{P}<0.001)$ corroborates with such results found. Cruz et al. (2010) determined a moderately positive correlation $(r=0.44)$ between RFI and cost-of-gain. Low-RFI animals showed costs lower by $19 \%$ than high-RFI animals (US\$ 1.65 vs. US\$ 2.03) and $8 \%$ lower than medianefficiency animals (US\$ 1.65 vs. US\$ 1.80), although the results were statistically similar (Table 2).

The group of high-efficiency animals was the only profitable group within the evaluation period (US\$ 0.14 per day; $\mathrm{P}<0.05$ ), whereas median- and low-efficiency animals caused losses of US\$ -0.18 and US\$ -0.64 , respectively, given the increased feed intake for the same weight gain (Table 2). Thus, the difference in mean return or loss between groups of high- and low-RFI animals was US\$ 0.78 per day, or US\$ 42.12 in the total feedlot period, which is a significant value for the breeding unit. This is especially so when applied to large commercial feedlots, thereby financially justifying the inclusion of RFI in genetic breeding programs. A strong negative correlation was observed between RFI and profit $(\mathrm{r}=-0.78 ; \mathrm{P}<0.001)$.

The decrease in cost-of-gain, and consequent increase in profit with decrease in RFI, is explained because these indices are mainly based on feed intake, which accounts for the highest costs of beef cattle farming. These costs may be between 70 and $80 \%$ of the total costs of the breeding unit (Archer et al., 2004). Several authors have demonstrated the importance of RFI for decreasing these costs. Crews Jr. (2006) observed that savings in daily feed costs per animal of up to US\$ 0.18 , which corresponds to US\$ 27.00 in a 150-day feedlot period, might be achieved when comparing high- and low-RFI animals. Carstens and Tedeschi (2006) observed savings of US\$ 38.00 per animal when evaluating steers from different efficiency classes for 120 days, and Basarab et al. (2003) calculated a difference of US\$ 45.60 in feed costs between high- and low-RFI animals in the same period.

No significant differences in ultrasound carcass traits were observed between efficiency groups ( $>>0.05$; Table 3) when considering the REA, BFT, RFT and REA ratio in both evaluations (day 0 and day 54). Gomes et al. (2012) and Santana et al. (2012) did not find any differences between the initial and final measurements of REA, BFT, and RFT in high- and low-RFI feedlot Nellore steers. Other researchers also found no differences in REA and BFT when evaluating high- and low-RFI Angus and crossbred Angus $\times$ Hereford steers (Baker et al., 2006; Sainz et al., 2010).

There were found weak phenotypic correlations between RFI and REA ( $\mathrm{r}=-0.28)$, BFT $(\mathrm{r}=0.20)$ and RFT ( $\mathrm{r}=0.26)$, all not significant $(\mathrm{P}>0.05)$. Arthur et al. (2001) observed weak and positive genetic and phenotypic correlations between RFI and measurements of REA, BFT and RFT in taurine breeds, which is similar to the findings of Santana et al. (2012), who found weak phenotypic correlations between the initial and final measurements of REA and BFT in feedlot zebu cattle.

However, high-efficiency animals had a larger REA adjusted for live weight (REA $100 \mathrm{~kg}^{-1}$ ) at the beginning of the feedlot period $(\mathrm{P}<0.05$; Table 3), because this group had a REA that was $7.5 \mathrm{~cm}^{2}$ larger than low-efficiency animals at this same time point, despite non-significant differences in live weight and muscle. Furthermore, low-RFI animals showed noticeably higher muscle gains in the growth phase than high-RFI animals, and this 
relationship may be established because all animals were derived from the same contemporary group. The REA $100 \mathrm{~kg}^{-1}$ is calculated to reduce the live weight effect, adjusting the comparison between individuals (Bergen et al., 1997), and favors small-sized animals, which tend to have earlier fat deposition in the carcass (BIF, 2002).

Table 3. Carcass traits of Brahman bulls determined by ultrasound, classified according to residual feed intake

\begin{tabular}{|c|c|c|c|c|c|}
\hline \multirow{2}{*}{ Traits } & \multicolumn{3}{|c|}{$\mathrm{RFI}^{\mathrm{I}}$} & \multirow{2}{*}{$\mathrm{SEM}^{2}$} & \multirow{2}{*}{$\mathrm{P}>\mathrm{F}^{3}$} \\
\hline & High & Medium & Low & & \\
\hline \multicolumn{6}{|c|}{ Start of the feedlot period (day 0$)$} \\
\hline $\mathrm{REA}, \mathrm{cm}^{2}$ & 58.22 & 60.28 & 65.72 & 1.38 & 0.18 \\
\hline REA $100 \mathrm{~kg}^{-1}, \mathrm{~cm}^{2}$ & $15.35^{\mathrm{b}}$ & $16.18^{\mathrm{b}}$ & $17.76^{\mathrm{a}}$ & 0.29 & 0.014 \\
\hline REA ratio & 0.47 & 0.45 & 0.44 & 0.01 & 0.09 \\
\hline $\mathrm{BFT}, \mathrm{mm}$ & 2.28 & 2.36 & 2.43 & 0.05 & 0.68 \\
\hline RFT, mm & 4.62 & 4.06 & 4.28 & 0.15 & 0.47 \\
\hline \multicolumn{6}{|c|}{ End of the feedlot period (day 54) } \\
\hline $\mathrm{REA}, \mathrm{cm}^{2}$ & 85.63 & 83.10 & 90.87 & 2.12 & 0.29 \\
\hline REA $100 \mathrm{~kg}^{-1}, \mathrm{~cm}^{2}$ & 17.66 & 17.10 & 18.72 & 0.37 & 0.14 \\
\hline REA ratio & 0.48 & 0.48 & 0.48 & 0.01 & 0.98 \\
\hline $\mathrm{BFT}, \mathrm{mm}$ & 4.54 & 4.05 & 3.83 & 0.36 & 0.83 \\
\hline RFT, mm & 8.25 & 7.75 & 7.32 & 0.38 & 0.76 \\
\hline \multicolumn{6}{|c|}{ Feedlot gains } \\
\hline $\mathrm{REA}, \mathrm{cm}^{2}$ & 27.41 & 22.82 & 25.15 & 1.69 & 0.51 \\
\hline REA $100 \mathrm{~kg}^{-1}, \mathrm{~cm}^{2}$ & 2.31 & 0.91 & 0.96 & 0.37 & 0.27 \\
\hline REA ratio & 0.00 & 0.03 & 0.04 & 0.01 & 0.46 \\
\hline BFT, mm & 2.26 & 1.69 & 1.40 & 0.35 & 0.74 \\
\hline RFT, mm & 3.62 & 3.69 & 3.04 & 0.38 & 0.79 \\
\hline
\end{tabular}

REA = ribeye area; REA $100 \mathrm{~kg}^{-1}=$ ribeye area adjusted for $100 \mathrm{~kg}$ live weight; REA ratio = ratio between ribeye height and width; BFT = Longissimus dorsi (ribeye) subcutaneous fat thickness; RFT = Biceps femoris (rump, RP) subcutaneous fat thickness.

${ }^{1}$ RFI = residual feed intake; least squares means followed by different letters are different according to the adjusted Tukey-Kramer test $(\alpha=0.05)$.

${ }^{2}$ Standard error of the mean.

${ }^{3}$ Type I error rate or significance level.

No effect of RFI on gains in REA, REA $100 \mathrm{~kg}^{-1}$, $\mathrm{BFT}, \mathrm{RFT}$ and REA ratio was recorded in the feedlot period ( $\mathrm{P}>0.05)$. Cruz et al. (2010) also found no differences in muscle and fat over the Longissimus dorsi in high- and low-RFI animals when evaluating crossbred Angus $\times$ Hereford steers. Lancaster et al. (2009) found no correlation between RFI and gains in REA or marbling, and also observed a weak positive correlation between RFI and gains in BFT, as did Arthur et al. (2001).

In the present study, the measurement of Longissimus dorsi subcutaneous fat assessed at the end of the feedlot period was higher than the three-millimeter standard, which is required to ensure efficient thermal insulation during carcass cooling, thus helping to prevent the coldshortening process (Luchiari Filho, 2000).
Gomes et al. (2012) and Santana et al. (2012) also found no significant differences in gains in REA and BFT in Nellore cattle from different RFI classes, despite noting that high-RFI animals had higher RFT values. Santana et al. (2012) recorded a 0.36 correlation between these indices.

Studies indicate that changes in body composition account for 5 to $9 \%$ of the RFI variation, and this trait is one of the main limiting factors in selection for this efficiency measure (Herd et al., 2004; Lancaster et al., 2009). Studies evaluating the relationships between RFI and carcass traits usually report results with large variations, and show that correlations between such traits are weak to moderate (Arthur et al., 2001; Nkrumah et al., 2004; Baker et al., 2006; Lancaster et al., 2009; 
Santana et al., 2012). Thus, the results obtained should be carefully analyzed, and such variations further clarified.

\section{CONCLUSIONS}

Residual feed intake is a viable selection strategy for increasing the profitability of beef cattle farming because it promotes reduced production costs, given the decreased dry matter intake of high-efficiency animals, without changing adult weight or weight gain. Furthermore, RFI has no adverse effect on carcass traits or significant effect on muscle and subcutaneous fat gains, thereby enabling the production of carcasses that meet the quality requirements for meat production for the consumer market.

\section{ACKNOWLEDGEMENTS}

The authors thank the CAPES agency (Coordination for the Improvement of Higher Education Personnel) for granting the scholarships.

\section{REFERENCES}

AHOLA, J.K.; SKOW, T.A.; HUNT, C.W.; HILL, R.A. Relationship between residual feed intake and end product palatability in longissimus steaks from steers sired by Angus bulls divergent for intramuscular fat expected progeny difference. Prof. Anim. Sci., v.27, p.109$115,2011$.

ARCHER, J.A.; BARWICK, S.A.; GRASER, H.U. Economic evaluation of beef cattle breeding schemes incorporating performance testing of young bulls for feed intake. Aust. J. Exp. Agric., v.44, p.393-404, 2004.

ARTHUR, P.F.; ARCHER, J.A.; JOHNSTON, D.J. et al. Genetic and phenotypic variance and covariance components for feed intake, feed efficiency, and other postweaning traits in Angus cattle. J. Anim. Sci., v.79, p.2805-2811, 2001.

BAKER, S.D.; SZASZ, J.I.; KLEIN, T.A. et al. Residual feed intake of purebred Angus steers: effects on meat quality and palatability. J. Anim. Sci., v.84, p.938-945, 2006.

BASARAB, J.A.; PRICE, M.A.; AALHUS, J.L. et al. Residual feed intake and body composition in young growing cattle. Can. J. Anim. Sci., v.83, p.189-204, 2003.
BERGEN, R.D.; MCKINNON, J.J.; CHRISTENSEN, D.A. et al. Use of the real-time ultrasound to evaluate live animal carcass traits in young performance-tested beef bulls. J. Anim. Sci., v.75, p.2300-2307, 1997.

BERRY, D.P.; CROWLEY, J.J. Residual intake and body weight gain: a new measure of efficiency in growing cattle. J. Anim. Sci., v.90, p.109-115, 2012.

BIF - Beef Improvement Federation. Guidelines for uniform beef improvement programs. Athens: Animal \& Dairy Science Department, The University of Georgia, 2002. 161p.

BINGHAM, G.M.; FRIEND, T.H.; LANCASTER. P.A.; CARSTENS, G.E. Relationship between feeding behavior and residual feed intake in growing Brangus heifers. J. Anim. Sci., v.87, p.2685-2689, 2009.

CARSTENS, G.; TEDESCHI, L. Defining feed efficiency in beef cattle. In: BEEF IMPROVEMENT FEDERATION, 38., 2006, Mississipi. Proceedings... Mississipi: BIF, 2006. p.12-21.

CASTRO BULLE, F.C.; PAULINO, F.C.P.; SANCHES, A.C.; SAINZ, R.D. Growth, carcass quality and protein and energy metabolism in beef cattle with different growth potentials and residual feed intakes. J. Anim. Sci., v.85, p.928936, 2007.

CREWS, JR. D.H. The genetics of feed efficiency in beef cattle. In: BEEF IMPROVEMENT FEDERATION, 38., 2006, Mississipi. Proceedings... Mississipi: BIF, 2006. p.22-30.

CROWLEY, J.J.; MCGEE, M.; KENNY D.A. et al. Phenotypic and genetic parameters for different measures of feed efficiency in different breeds of Irish performance-tested beef bulls. $J$. Anim. Sci., v.88, p.885-894, 2010.

CRUZ, G.D.; SÁNCHEZ, J.A.R; OLTJEN, J.W.; SAINZ, R.D. Performance, residual feed intake, digestibility, carcass traits, and profitability of Angus-Hereford steers housed in individual or group pens. J. Anim. Sci., v.88, p.324-329, 2010.

DETMANN, E.; SOUZA, M.A.; VALADARES FILHO, S.C. et al. Métodos para análise de alimentos. Visconde do Rio Branco: Suprema, 2012. 214p. 
GOMES, R.C.; SAINZ, R.D.; SILVA, S.L. et al. Feedlot performance, feed efficiency reranking, carcass traits, body composition, energy requirements, meat quality and calpain system activity in Nellore steers with low and high residual feed intake. Livest. Sci., v.150, p.265273,2012

HERD, R.M.; BISHOP, S.C. Genetic variation in residual feed intake and its association with other production traits in British Hereford cattle. Livest. Prod. Sci., v.63, p.111-119, 2000.

HERD, R.M.; ODDY, V.H.; RICHARDSON, E.C. Biological basis for variations in residual feed intake in beef cattle. Review of potential mechanisms. Aust. J. Exp. Agric., v.44, p.423430, 2004.

KOCH, R.M.; SWIGER, L.A.; CHAMBERS, D.; GREGORY, K.E. Efficiency of feed use in beef cattle. J. Anim. Sci., v.22, p.486-494, 1963.

LANCASTER, P.A.; CARSTENS, G.E.; CREWS JR., D.H. et al. Phenotypic and genetic relationships of residual feed intake with performance and ultrasound carcass characteristics of Brangus heifers. J. Anim. Sci., v.87, p.3887-3896, 2009.

LUCHIARI FILHO, A. Pecuária da carne bovina. São Paulo: Albino Luchiari Filho, 2000. $134 \mathrm{p}$.

MIZUBUTI, I.Y.; PINTO, A.P.P.; PEREIRA, E.S.; RAMOS, B.M.O. Métodos laboratoriais de avaliação de alimentos para animais. Londrina: EDUEL, 2009. 228p.

NKRUMAH, J.D.; BASARAB, J.A.; PRICE, M.A. et al. Different measures of energetic efficiency and their phenotypic relationships with growth, feed intake, and ultrasound and carcass merit in hybrid cattle. J. Anim. Sci., v.82, p.2451-2459, 2004.
NKRUMAH, J.D.; BASARAB, J.A.; WANG, Z. et al. Genetic and phenotypic relationships of feed intake and different measures of feed efficiency with growth and carcass merit of beef cattle. J. Anim. Sci., v.85, p.2711-2720, 2007.

NKRUMAH, J.D.; OKINE, E.K.; MATHISON, G.W. et al. Relationships of feedlot, feed efficiency, performance, and feeding behavior with metabolic rate, methane production, and energy partitioning in beef cattle. J. Anim. Sci., v.84, p.145-153, 2006.

NUTRIENT requirements of beef cattle. 6.ed. Washington: National Academy Press, 1996. 90p.

SAINZ, R.D.; CRUZ, G.D.; SÁNCHEZ, J.A.R.; OLTJEN, J.W. Performance, residual feed intake, digestibility, carcass traits, and profitability of Angus-Hereford steers housed in individual or group pens. J. Anim. Sci., v.88, p.324-329, 2010.

SANTANA, M.H.A.; ROSSI JR., P.; ALMEIDA, R.; CUCCO, D.C. Feed efficiency and its correlations with carcass traits measured by ultrasound in Nellore bulls. Livest. Sci., v.145, p.252-257, 2012.

STATISTICAL analysis system. Version 9.2. Cary: SAS Institute, 2008.

WEISS, W.P.; CONRAD, H.R.; PIERRE N.R.St. A theoretically-based model for predicting total digestible nutrient values of forages and concentrates. Anim. Feed Sci. Technol., v.39, p.95-110, 1992.

ZORZI, K.; BONILHA, S.F.M.; QUEIROZ, A.C. et al. Meat quality of young Nellore bulls with low and high residual feed intake. Meat Sci., v.93, p.593-599, 2013. 